\title{
Kepemimpinan, Kepuasan Kerja dan Motivasi terhadap Kinerja Pegawai
}

\author{
Roy Sahputra Saragih ${ }^{1 *}$, Hengki Mangiring Parulian Simarmata ${ }^{1}$ \\ ${ }^{1}$ Program Studi Manajemen Perkantoran, Politeknik Bisnis Indonesia Murni Sadar Pematangsiantar \\ Jl. Sriwijaya NO. 9 C-E Pematangsiantar, Sumatera Utara, Indonesia 2114 \\ *Email: roysahputra31@yahoo.com
}

\begin{tabular}{|c|c|}
\hline Artikel Info & ABSTRAK \\
\hline $\begin{array}{l}\text { Received: } \\
20 \text { Agustus } 2018 \\
\quad \text { Revised: } \\
\text { 10 September } 2018 \\
\text { Accepted: } \\
\text { 30 September } 2018\end{array}$ & $\begin{array}{l}\text { Penelitian ini bertujuan untuk menganalisis pengaruh kepemimpinandan kepuasan } \\
\text { terhadap Kinerja pegawai dengan Motivasi sebagai variabel intervening. Sampel yang } \\
\text { digunakan sebanyak } 100 \text { responden. Metode Pengumpulan data dengan menggunakan } \\
\text { kuesioner dan wawancara. Teknik analisa data yang digunakan pada penelitian ini } \\
\text { adalah Path analysis. Hasil penelitian ini membuktikan bahwa terdapat pengaruh yang } \\
\text { signifikan antara kinerja pegawai dengan kepemimpinan, kepemimpinan dengan }\end{array}$ \\
\hline & $\begin{array}{l}\text { kepuasan, kepemimpinan dengan motivasi kerja, kepuasan dengan motivasi kerja, } \\
\text { kinerja pegawai dengan kepuasan, kinerja pegawai dengan motivasi kerja. Analisis jalur } \\
\text { menunjukkan kepemimpinan, kepuasan, dan motivasi kerja, memiliki pengaruh } \\
\text { terhadap perubahan variabel kinerja pegawai. }\end{array}$ \\
\hline
\end{tabular}

Kata Kunci: Kepemimpinan, kepuasan kerja, motivasi, kinerja

Leadership, Job Satisfaction and Motivation on Employee Performance

\begin{abstract}
This study aims to analyze the influence of leadership and satisfaction on employee performance with motivation as an intervening variable. The sample used was 100 respondents. Data collection method using questionnaires and interviews. The data analysis technique used in this study is Path analysis. The results of this study prove that there is a significant influence between employee performance and leadership, leadership with satisfaction, leadership with work motivation, satisfaction with work motivation, employee performance with satisfaction, employee performance with work motivation. Path analysis shows leadership, satisfaction, and work motivation influences changes in employee performance variables.
\end{abstract}

Keywords: Leadership, job satisfaction, motivation, performance

\footnotetext{
Cara Sitasi :

Saragih, R. S. (2018). Kepemimpinan, Kepuasan Kerja dan Motivasi terhadap Kinerja Pegawai, 19(2), $124-133$. https://doi.org/ 10.30596/jimb.v19i2.2146.
} 


\section{PENDAHULUAN}

Proses pembangunan nasional yang berlangsung dewasa ini sedang mengalami pergeseran dari bingkai sistem otoriter ke sistem demokrasi. Hal ini menyebabkan penyelenggaraan pemerintahan menjadi sorotan yang tajam, terutama dalam aspek transparansi, akuntabilitas, efisiensi dan efektifitas. Dalam konteks ini, penerapan prinsip-prinsip good governance dalam pengelolaan pemerintahan menjadi suatu tuntutan utama, oleh karena masyarakat mulai kritis dalam memonitor dan mengevaluasi manfaat serta nilai yang diperoleh atas pelayanan dari instansi pemerintah. Disisi lain, pengukuran keberhasilan maupun kegagalan instansi pemerintah dalam menjalankan tugas pokok dan fungsinya sulit dilakukan secara obyektif, disebabkan oleh karena belum diterapkannya sistem pengukuran kinerja, yang dapat menginformasikan tingkat keberhasilan secara obyektif dan terukur dari pelaksanaan program-program disuatu instansi pemerintah.

Suatu organisasi didirikan sebagai suatu wadah untuk mencapai suatu atau beberapa tujuan. Organisasi tersebut harus mengelolah berbagai dan rangkaian kegiatan yang diarahkan menuju tercapainya tujuan organisasi. Pelaksanakan rangkaian kegiatan dalam organisasi dilakukan oleh manusia (humanbeing) yang bertindak sebagai aktor atau peserta dalam organisasi yang bersangkutan, maka dengan sendirinya kinerja (performance) organisasi yang bersangkutan banyak tergantung pada perilaku manusia yang terdapat dalam organisasi tersebut.

Kinerja birokrasi publik sangat dipengaruhi oleh budaya paternalisme yang masih sangat kuat, yang cenderung mendorong pejabat birokrasi untuk lebih berorientasi pada kekuasaan daripada pelayanan, menempatkan dirinya sebagai penguasa dan memperlakukan para pengguna jasa sebagai obyek pelayanan yang membutuhkan bantuannya. Disamping itu, rendahnya kinerja juga disebabkan oleh sistem pembagian kekuasaan yang cenderung memusat pada pimpinan. Struktur birokrasi yang hierarkis mendorong adanya pemusatan kekuasaan dan wewenang pada atasan sehingga pejabat birokrasi yang langsung berhubungan dengan para pengguna jasa sering tidak memiliki wewenang yang memadai untuk merespons dinamika yang berkembang dalam penyelenggaraan pelayanan

Bagi Sekretariat Daerah Kabupaten Simalungun sebagai organisasi yang mengemban fungsi koordinasi dan pelayanan teknis administrasi kepada seluruh perangkat/instansi vertikal pemerintah daerah maka penilaian kinerja bagi aparatur organisasi memiliki arti yang sangat penting terutama dalam upaya melakukan perbaikan-perbaikan pada masa yang akan datang. Penilaian kinerja bagi aparatur berguna untuk menilai kuantitas, kualitas dan efisiensi pelayanan, motivasi, dan guna penyesuaian anggaran organisasi. Tetapi persoalannya, apakah penilaian yang dilakukan telah menggambarkan kinerja yang sebenarnya. Hal ini akan sangat ditentukan oleh ketajaman dalam menentukan cakupan, cara dan indikatorindikator yang digunakan. Suatu penilaian yang menggunakan cakupan, cara dan indikator yang sangat terbatas akan memberikan hasil yang sangat terbatas pula dan berarti kurang menggambarkan keadaan yang sebenarnya. Selama ini, penilaian secara sistematik terhadap kinerja aparatur belum menjadi tradisi, sehingga berakibat pada munculnya perdebatan yang tidak terselesaikan ketika terjadi hasil penilaian yang berbeda antara pihak yang satu dengan lainnya.

Kepuasan kerja adalah sebagai perasaan seseorang terhadap pekerjaannya. Ini berarti bahwa konsepsi kepuasan kerja 
itu sebagai hasil interaksi manusia dengan lingkungan kerjanya. Dari batasan tentang kepuasan kerja tersebut, organisasi harus mampu mengidentifikasi dan berusaha mengetahui apa yang diharapkan dari hasil pekerjaannya. Harapan tersebut dapat diidentifikasi secara tepat apabila pimpinan dapat mengerti persepsi pegawai terhadap kepuasan. Mengetahui persepsi pegawai terhadap kepuasan sangatlah penting, agar tidak terjadi kesenjangan (gap) persepsi antara pimpinan dengan pegawa.

Motivasi juga merupakan hal yang penting bagi pegawai. Motivasi pada dasarnya adalah proses untuk mencoba mempengaruhi seseorang agar melakukan sesuatu yang kita inginkan, baik dorongan dari luar ataupun dari dalam agar seseorang mau melaksanakan sesuatu (Martoyo, 2002). Dari uraian tersebut, motivasi pegawai mempunyai andil besar dalam meningkatkan kinerja pegawai, dan pegawai akan termotivasi dan merasa puas apabila kebutuhan baik fisik maupun psikologis terpenuhi, semakin terpenuhi kebutuhan tersebut, maka seorang pegawai akan semakin tinggi motivasi dan kepuasan kerjanya.

Disisi lain, kepemimpinan adalah fenomena yang terdapat dalam setiap komunitas, karena dimana manusia berinteraksi maka disana timbul fenomena kepemimpinan, mulai dari interaksi dalam kelompok yang paling primitif sampai ke yang paling maju, mulai dari kelompok yang paling terkecil sampai ke organisasi yang paling besar. Faktor kepemimpinan dalam suatu organisasi menjadi sangat penting manakala individu/anggota organisasi memiliki dinamika yang tinggi dalam aktivitasnya disamping perubahan terus menerus yang didorong oleh kemajuan teknologi, kata kunci dari fenomena ini adalah kemampuan untuk mempengaruhi anggota organisasi sehingga mereka dengan segala kesungguhan berusaha untuk mencapai tujuan organisasi yang telah ditetapkan sebelumnya.

Penilaian kinerja aparatur merupakan suatu kegiatan yang sangat penting karena dapat digunakan sebagai ukuran keberhasilan organisasi dalam mencapai misinya. Sekretariat Daerah Kabupaten Simalungun sebagai organisasi publik yang memiliki tugas pokok dan fungsi koordinasi dan memberikan pelayanan administrasi memerlukan informasi mengenai kinerja aparatur yang ada di dalam organisasi, sehingga dapat dilakukan penilaian seberapa jauh pelayanan yang diberikan oleh organisasi dapat memenuhi harapan dan memuaskan pengguna jasa. Terbatasnya informasi mengenai kinerja aparatur terjadi karena kinerja belum dianggap sebagai suatu hal yang penting dan hal ini menunjukan ketidak seriusan pemerintah untuk menjadikan kinerja sebagai agenda kebijakan yang penting, sehingga tidak jarang ditemukan dalam perekrutan suatu jabatan yang didasarkan pada pertimbangan like and dislike pimpinan.

\section{METODE}

Penelitian ini menggunakan pendekatan kuantitatif yang mengunakan angka-angka statistic dalam melakukan analisis. Populasi dalam Penelitian ini adalah pegawai Sekretaris Daerah Kabupaten Simalungun. Sample penelitian ini adalah sampleh jenuh sehingg semua populasi pada penelitian ini digunakan sebagai sample yang berjumlah 100 pegawai. Pengumpulan dana dilakukan menggunakan kuisioner dan wawancara. Sebelum dilakukan analisis terhadap dta penelitian, maka dilakukan uji validitas, dan reliabilitas kuisioner sehingga kuisioner layak untuk disebarkan, hasil pengujian validitas menunjukkan $r_{\text {hitung }}>r$ tabel sedangkan uji reliabilitas menujukkan nilai cronbach alpha $>0,7$ sehingga kuisioner ini layak 


\section{Published Oktober 2018 \\ JURNAL ILMIAH MANAJEMEN DAN BISNIS \\ ISSN 1693-7619 (print) | ISSN 2580-4170 (online), http://jurnal.umsu.ac.id/index.php/mbisnis}

untuk digunakan. Teknik analisa data yang digunakan pada penelitian ini adalah path analysis,

\section{HASIL DAN PEMBAHASAN}

Untuk mencari hubungan kausal atau pengaruh variabel-variabel penelitian, terlebih dahulu dihitung matriks korelasi dari variabel-variabel kepemimpinan, motivasi, kepuasan kerja, dan kinerja pegawai. Berikut adalah hasil penghitungan koefisien korelasi dengan menggunakan software SPSS dengan melihat nilai Pearson Correlation Sig. (2tailed) seperti terlihat pada tabel 1 .

Pengujian berdasarkan uji probabilitas (prob): Jika Probabilitas > 0.05, maka $\mathrm{H}_{0}$ diterima. Jika Probabilitas < 0.05 , maka $\mathrm{H}_{0}$ ditolak. Berdasarkan hasil pengujian di atas, maka dapat disimpulkan dengan Tabel yang terdapat dibawah ini:

Tabel 1. Pengujian Hubungan Antar Sub Variabel

\begin{tabular}{|l|c|l|c|c|}
\hline \multicolumn{1}{|c|}{ Hubungan } & $\begin{array}{c}\text { Koefisien } \\
\text { Korelasi }\end{array}$ & Kategori & $\begin{array}{c}\text { Proba } \\
\text { bilitas }\end{array}$ & Kesimpulan \\
\hline $\begin{array}{l}\text { Kepemim } \\
\text { pinan } \rightarrow \\
\text { Kinerja }\end{array}$ & 0.165 & $\begin{array}{l}\text { Sangat } \\
\text { Rendah }\end{array}$ & 0.040 & Signifikan \\
\hline $\begin{array}{l}\text { Kepuasan } \\
\rightarrow \text { Kinerja }\end{array}$ & 0.702 & Kuat & 0.000 & Signifikan \\
\hline $\begin{array}{l}\text { Motivasi } \\
\rightarrow \text { Kinerja }\end{array}$ & 0.412 & Sedang & 0.000 & Signifikan \\
\hline $\begin{array}{l}\text { Kepemimpinan } \\
\rightarrow \text { Kepuasan }\end{array}$ & 0.065 & $\begin{array}{l}\text { Sangat } \\
\text { Rendah }\end{array}$ & 0.023 & Signifikan \\
\hline $\begin{array}{l}\text { Kepemimpi } \\
\text { nan } \rightarrow \\
\text { Motivasi }\end{array}$ & 0.135 & $\begin{array}{l}\text { Sangat } \\
\text { Rendah }\end{array}$ & 0.032 & Signifikan \\
\hline $\begin{array}{l}\text { Kepuasan } \rightarrow \\
\text { Motivasi Kerja }\end{array}$ & 0.043 & $\begin{array}{l}\text { Sangat } \\
\text { Rendah }\end{array}$ & 0.022 & Signifikan \\
\hline
\end{tabular}

Tabel 1, diketahui bahwa variabel memiliki nilai probabilitas dibawah 0.05 . Hal ini dapat diartikan bahwa terdapat hubungan yang signifikan yaitu antara kinerja pegawai (Y) dengan kepemimpinan $\left(\mathrm{X}_{1}\right)$, kepemimpinan $\left(\mathrm{X}_{1}\right)$ dengan kepuasan $\left(\mathrm{X}_{2}\right)$, kepemimpinan $\left(\mathrm{X}_{1}\right)$ dengan motivasi kerja $(\mathrm{Z})$, kepuasan $\left(\mathrm{X}_{2}\right)$ dengan motivasi kerja $(\mathrm{Z})$, kinerja pegawai (Y) dengan kepuasan $\left(\mathrm{X}_{2}\right)$, kinerja pegawai (Y) dengan motivasi kerja (Z).

Untuk pengujian Hipotesis dapat dilihat pada Tabel 3 .

Tabel 2. Hasil uji t

\begin{tabular}{|c|c|c|c|c|c|c|}
\hline \multirow{2}{*}{\multicolumn{2}{|c|}{ Model }} & \multicolumn{2}{|c|}{$\begin{array}{l}\text { Unstandardized } \\
\text { Coefficients }\end{array}$} & $\begin{array}{l}\text { Standardized } \\
\text { Coefficients }\end{array}$ & \multirow[t]{2}{*}{$\mathbf{t}$} & \multirow[t]{2}{*}{ Sig } \\
\hline & & B & $\begin{array}{l}\text { Std. } \\
\text { Error }\end{array}$ & Beta & & \\
\hline \multirow[t]{4}{*}{$\overline{1}$} & (Constant) & 2.080 & 3.715 & & .560 & .577 \\
\hline & Kepemimpinan & .047 & .041 & & .0712 .153 & .022 \\
\hline & Motivasi Kerja & .590 & .097 & & .3736 .075 & .000 \\
\hline & Kepuasan & .726 & .065 & & $\begin{array}{r}.68211 .16 \\
7\end{array}$ & .000 \\
\hline
\end{tabular}

Dengan Persamaan : $Z=\rho Z x 1 X 1+$ $\rho Z x 2 X 2+\rho Z Y Z+\varepsilon 2$ Terlihat bahwa thitung untuk koefisien kepemimpinan adalah 2.153, sedang tTabel bisa dihitung pada Tabel t-test, dengan $\alpha=0.05$, karena digunakan hipotesis dua arah, ketika mencari tTabel, nilai $\alpha$ dibagi dua menjadi 0.025 , dan $\mathrm{df}=97$ (didapat dari rumus $\mathrm{n}-\mathrm{k}$, dimana $n$ adalah jumlah data, $100-3=97$ ). Didapat $\mathrm{t}_{\text {Tabel }}$ adalah 1.98. Oleh karena $\mathrm{t}_{\text {hitung }}$ $>\mathrm{t}_{\text {Tabel}},(2.153>1.98)$, maka $\mathrm{H}_{0}$ ditolak, sehingga dapat disimpulkan bahwa koefisien kepemimpinan berpengaruh signifikan terhadap kinerja pegwai. Bahwa nilai probabilitas pada kolom Sig adalah 0.022 atau probabilitas dibawah 0.05 $(0.022<0.05)$. Dengan demikian $\mathrm{H}_{0}$ ditolak, sehingga mempunyai kesimpulan yang sama dengan uji $t$ yaitu koefisien kepemimpinan berpengaruh signifikan terhadap kinerja pegawai. Untuk menguji signifikansi koefisien $\rho_{Z} \mathrm{X}_{2}$ (kepuasan), terlihat bahwa thitung untuk koefisien kepuasan adalah 11.167, sedang $\mathrm{t}_{\text {Tabel }}$ bisa dihitung pada Tabel t-test, dengan $\alpha=0.05$, karena digunakan hipotesis dua arah, ketika mencari $\mathrm{t}_{\text {Tabel, }}$ nilai $\alpha$ dibagi dua menjadi 0.025 , dan $\mathrm{df}=$ 97 (didapat dari rumus $n-3$, dimana $n$ adalah jumlah data, $100-3=97$ ). Didapat $\mathrm{t}_{\mathrm{Tabel}}$ adalah 1.98. Oleh karena $t_{\text {hitung }}>\mathrm{t}_{\text {Tabel, }}$, 


\section{Published Oktober 2018 \\ JURNAL ILMIAH MANAJEMEN DAN BISNIS \\ ISSN 1693-7619 (print) | ISSN 2580-4170 (online), http://jurnal.umsu.ac.id/index.php/mbisnis}

(11.167 > 1.98), maka $\mathrm{H}_{0}$ ditolak, sehingga dapat disimpulkan bahwa koefisienkepuasan berpengaruh signifikan terhadap kinerja pegawai, nilai probabilitas pada kolom Sig adalah 0.000 atau probabilitas dibawah $0.05(0.000<0.05)$. Dengan demikian $\mathrm{H}_{0}$ ditolak, sehingga mempunyai kesimpulan yang sama dengan uji t yaitu koefisien kepuasan berpengaruh signifikan terhadap kinerja pegawai.

$t_{\text {hitung }}$ untuk koefisien motivasi kerja adalah 6.075, Sedang $\mathrm{t}_{\text {Tabel }}$ bisa dihitung pada Tabel t-test, dengan $\alpha=0.05$, karena digunakan hipotesis dua arah, ketika mencari $\mathrm{t}_{\text {Tabel }}$, nilai $\alpha$ dibagi dua menjadi 0.025 , dan $\mathrm{df}=97$ (didapat dari rumus n$\mathrm{k}$, dimana $\mathrm{n}$ adalah jumlah data, $100-3=$ 97). Didapat $t_{\text {Tabel }}$ adalah 1.98. Oleh karena $\mathrm{t}_{\text {hitung }}>\mathrm{t}_{\text {tabel }},(6.075>1.98)$, maka $\mathrm{H}_{0}$ ditolak, sehingga dapat disimpulkan bahwa koefisien motivasi kerja berpengaruh signifikan terhadap kinerja pegawai, nilai probabilitas pada kolom Sig adalah 0.000 atau probabilitas dibawah $0.05(0.000<0.05)$. Dengan demikian $\mathrm{H}_{0} \quad$ ditolak, sehingga mempunyai kesimpulan yang sama dengan uji t yaitu koefisien motivasi kerja berpengaruh signifikan terhadap kinerja pegawai.

Tabel 3. Pengujian Koefisien Jalur

\begin{tabular}{|c|c|c|c|c|c|}
\hline No & Hipotesis & $\begin{array}{l}\text { Koefisien } \\
\text { jalur }\end{array}$ & $\begin{array}{c}\mathbf{t} \\
\text { hitung }\end{array}$ & $\begin{array}{c}\mathbf{t} \\
\text { Tabel }\end{array}$ & $\begin{array}{c}\text { kesimpul } \\
\text { an }\end{array}$ \\
\hline 1 & $\begin{array}{l}\square \mathrm{ZX} 1 \\
\neq 0\end{array}$ & $\begin{array}{l}\square \mathrm{ZX} 1= \\
0.071\end{array}$ & 2.153 & 1.98 & Hoditolak \\
\hline 2 & $\begin{array}{l}\square \quad \mathrm{ZX} 2 \\
\neq\end{array}$ & $\begin{array}{l}\square \mathrm{ZX} 2 \\
0.373\end{array}$ & 11.167 & 1.98 & Hoditolak \\
\hline 3 & $\begin{array}{l}\square \\
\neq 0\end{array}$ & $\begin{array}{l}\square \mathrm{ZY} \\
0.682\end{array}$ & 6.075 & 1.98 & Hoditolak \\
\hline
\end{tabular}

Tabel 3, Dari hasil pengujian parsial diketahui bahwa untuk variabel kepemimpinan berpengaruh signifikan terhadap kinerja pegawai, variabel kepuasan berpengaruh signifikan terhadap kinerja pegawai, variabel motivasi kerja berpengaruh signifikan terhadap kinerja pegawai.

Tabel 4. Hasil uji F

\begin{tabular}{llrrrr}
\hline & Model & $\begin{array}{c}\text { Sum of } \\
\text { Squares }\end{array}$ & $\begin{array}{c}\text { Mean } \\
\text { Square }\end{array}$ & F & Sig. \\
\hline 1 & Regression & 1371.536 & 57.179 & 7.248 & $.000^{a}$ \\
& Residual & 757.304 & 7.889 & & \\
Total & 2128.840 & & & \\
& & & & & \\
\hline
\end{tabular}

Pada Tabel 4, hasil uji $\mathrm{F}$ yang dapat dipergunakan untuk menguji model apakah variabel kepemimpinan, kepuasan dan motivasi kerja secara simultan berpengaruh signifikan terhadap kinerja pegawai. Nilai $F_{\text {hitung }}$ sebesar 7.248. Dengan tingkat signifikansi sebesar $5 \%$ dan $\mathrm{df}_{1}=3$ dan $\mathrm{df}_{2}=96$, didapat nilai $\mathrm{F}_{\text {Tabel }}$ $=2.70$. Karena nilai $F_{\text {hitung }}(7.248)>$ nilai $\mathrm{F}_{\text {Tabel }}(2.70)$ maka $\mathrm{H}_{0}$ ditolak atau terdapat kecocokan antara model dengan data. Sehingga dapat disimpulkan bahwa aspek variabel kepemimpinan, kepuasan dan motivasi kerja secara simultan berpengaruh signifikan terhadap kinerja pegawai. Jika dilihat dengan menggunakan nilai signifikansi, diketahui bahwa nilai sig $(0.000<0.05)$ sehingga memiliki kesimpulan yang sama dengan uji $\mathrm{F}$ yaitu terdapat kecocokan antara model dengan data.

\section{PEMBAHASAN}

\section{Pengaruh kepemimpinan terhadap motivasi kerja}

Hasil uji hipotesis menunjukkan bahwa kepemimpinan berpengaruh signifikan terhadap motivasi kerja. kepemimpinan merupakan suatu kemampuan untuk mempengaruhi pihak lain, melalui motivasi baik intern maupun ekstern dengan maksud untuk menggerakkan orang-orang agar dengan 
pengertian, kesadaran, dan senang hati bersedia mengikuti kehendak pimpinan tersebut. Sebagai pemimpin, harus mampu menetapkan arah dengan mengembangkan suatu visi terhadap masa depan kemudian mereka menyatukan orang dengan mengkomunikasikan visi ini dan mengilhami mereka untuk mengatasi rintangan (Bahrum \& Sinaga, 2015); (Supendy, Setiawan, Troena, \& Surachman, 2012). Keadaan ini menggambarkan bahwa kepemimpinan sangat diperlukan, jika suatu organisasi atau perusahaan memiliki perbedaan dengan yang lain dapat dilihat dari sejauh mana pemimpinnya dapat bekerja secara efektif. Pemimpin juga berguna untuk menunjang keberhasilan fungsi manajemen dalam organisasi tentunya membutuhkan seorang pemimpin yang dapat melaksanakan tugas atau fungsi manajemen. Kepemimpinan adalah suatu faktor kemanusiaan, mengikat suatu kelompok bersama dan memberi motivasi kerja untuk tercapainya tujuan organisasi. Tanpa kepemimpinan yang efektif, individuindividu maupun kelompok cenderung tidak memiliki arah dan kurang termotivasi (Nugraha, 2016). Pemimpin yang profesional, kita akan lebih mudah memahami apa yang menjadi tujuan dalam bekerja. Keterbatasan sumber daya organisasi mengharuskan pemimpin untuk mengelolanya dengan efektif, dengan kata lain arah yang hendak dicapai oleh organisasi menuju tujuannya harus sedemikian rupa sehingga mengoptimalkan pemanfaatan dari segala sarana prasarana yang ada (Rawung, 2013). Dengan demikian dapat dikatakan kepemimpinan sangat erat hubungannya dengan motivasi kerja. Kepemimpinan yang memperoleh respon positif dari pegawai cenderung akan meningkatkan motivasi kerja pegawai, demikian bila terjadi sebaliknya (Pradana, 2015); (Alghazo \& Al-Anazi, 2016).

\section{Pengaruh kepuasan terhadap motivasi kerja}

Kepuasan berpengaruh signifikan terhadap motivasi kerja. Motivasi kerja merupakan dorongan dalam diri karyawan untuk melakukan suatu kegiatan atau tugas agar mampu mencapai kepuasan sesuai dengan keinginannya, motivasi kerja dapat diartikan sebagai keinginan atau kebutuhan akan kepuasan kerja yang melatar belakangi seseorang sehingga ia terdorong untuk bekerja. Motivasi kerja merupakan salah satu faktor yang turut menentukan puas tidaknya seseorang dalam bekerja (Azhari \& Syamsir, 2012). Besar atau kecilnya pengaruh motivasi pada kepuasan seseorang tergantung pada seberapa banyak intensitas motivasi yang diberikan. Perbedaan motivasi kerja bagi seorang karyawan biasanya tercermin dalam berbagai kegiatan dan bahkan prestasi yang dicapainya (Afifah \& Musadieq, 2017). Kepuasan kerja adalah suatu sikap positif yang menyangkut penyesuaian diri para karyawan terhadap pekerjaannya, jika karyawan merasa puas terhadap pekerjaannya, maka karyawan tersebut memiliki sikap positif dan bangga, serta menilai pekerjaannya tinggi, karena situasi dan kondisi kerja dapat memenuhi kebutuhan, keinginan, dan harapannya. Indikator-indikator yang mempengaruhi kepuasan kerja adalah sebagai berikut : gaji, kenyamanan, kebanggaan terhadap lembaga, penghargaan terhadap hasil kerja, kesempatan untuk maju, kebermaknaan tugas, kewenangan mengatur waktu dan umpan balik terhadap tugas itu sendiri. Jadi semakin tinggi kepuasan kerja karyawan, maka semakin tinggi kinerja karyawan tersebut. Semakin besar motivasi kerja karyawan semakin tinggi kepuasan kerjanya (Rasmi, et al., 2017; Octaviannand, et al., 2017; Cong \& Van, 2013) . Dengan demikian dapat dikatakan bahwa motivasi kerja adalah faktor yang sangat penting dalam peningkatan kepuasan kerja. 


\section{Pengaruh kepemimpinan terhadap kinerja pegawai}

Kepemimpinan berpengaruh signifikan terhadap kinerja pegawai. Kepemimpinan memiliki hubungan yang erat dengan kinerja karyawan. Kinerja karyawan tidak hanya dilihat dari skill saja namun juga dilihat dari cara seseorang itu memipin dan mempengaruhi kawan sepekerjaannya untuk mencapai tujuan yang menguntungkan perusahaannya (Muizu, 2014) . Seorang pemimpin harus mampu berkontribusi terhadap prediksi adanya pemberdayaan pada bawahan (Basit \& Sebastian, 2017) . Dalam hal ini pemimpin perusahaan juga dituntut untuk memotivasi bawahannya agar mereka mempertahankan prestasinya dalam dunia kerja dan terus bias menghasilkan hasil kinerja yang efektif (Iqbal, Anwar, \& Haider, 2015; Octaviannand et al., 2017; Nasution, 2018). Faktor kepemimpinan juga berpengaruh terhadap kinerja karyawan, dari pendapat para ahli tersebut dapat disimpulkan bahwa terdapat hubungan yang erat dan pengaruh antara faktor kepemimpinan dan faktor kinerja karyawan.

\section{Pengaruh kepuasan terhadap kinerja pegawai}

Kepuasan kerja berpengaruh signifikan terhadap kinerja pegawai. Kepuasan kerja pada tingkat tertentu dapat mencegah karyawan untuk mencari pekerjaan diperusahaan lain. Apabila karyawan di perusahaan tersebut mendapatkan kepuasan, karyawan cenderung akan bertahan pada perusahaan walaupun tidak semua aspek-aspek yang mempengaruhi kepuasan kerja terpenuhi (Rindiantika \& Susilo, 2018). Karyawan yang memperoleh kepuasan dari perusahaannya akan memiliki rasa keterikatan atau komitmen lebih besar terhadap perusahaan dibanding karyawan yang tidak puas (Khan, et al., 2012;
Fadlallh, 2015). kepuasan kerja (job satisfaction) merupakan keadaan emosional yang menyenangkan atau tidak menyenangkan dengan mana karyawan memandang pekerjaan mereka. Pendapat tersebut dapat dipahami bahwa karyawan harus ditempatkan pada pekerjaan yang sesuai dengan kemampuan dan latar belakang ketrampilannya. Dengan demikian kepuasan kerja sangat berdampak pada kinerja karyawan.

\section{Pengaruh motivasi kerja terhadap kinerja pegawai. \\ Motivasi berpengaruh signifikan} terhadap kinerja pegawai. Motivasi kerja karyawan amat sangat dibutuhkan untuk suatu pekerjaan, karena pada dasarnya manusia mudah dimotivasi dengan memberikan apa yang menjadi keinginannya. Pentingnya motivasi dalam organisasi sehingga menyebabkan seseorang akan bekerja jika ada motif karena tanpa motif, orang tidak akan berbuat sesuatu (Omollo \& Oloko, 2015). Motif dapat timbul dari dalam karena adanya kebutuhan dasar manusia yang bersifat universal tetapi tidak dapat pula dirangsang. Rangsangan dari luar dapat berbentuk fisik atau non fisik yang disebut dengan motivasi sedangakan bendanya dinamakan motivator. Dari beberapa penelitian disebutkan motivasi berpengaruh positif dan signifikan terhadap kinerja karyawan, dan dalam penelitian ini juga menyatakan bahwa motivasi merupakan factor dominan yang mempengaruhi kinerja karyawan. Hubungan anatara motivasi dan kinerja karyawan yaitu semakin tinggi motivasi karyawan dalam bekerja maka kinerja yang dihasilkan juga semakin efektif dan kompeten di dalam bidangnya (Ali, et al., 2016) Proses belajar harus menjadi budaya perusahaan sehingga keterampilan para karyawan dapat dipelihara. Dalam hal ini loyalitas karyawan yang kompeten haruas diperhatikan. Oleh 
sebab itu motivasi dapat dikatakan sebagai suatu pemberian pengarahan, dorongan atau semangat kepada para karyawan agar mampu bekerja sesuai dengan tujuan yang diharapkan, demi tercapainya tujuan organisasi dalam suatu perusahaan dengan efektif dan efisien. menunjukan bahwa semakin kuat motivasi kerja, kinerja pegawai akan semakin tinggi (Shahzadi, et al., 2014); Onanda, 2015; Hal ini berarti bahwa setiap peningkatan motivasi kerja pegawai akan memberikan peningkatan yang sangat berarti bagi peningkatan kinerja pegawai dalam melaksanakan pekerjaannya. Motivasi merupakan faktor yang mempengaruhi semangat dan kegairahan kerja karyawan untuk berperan serta secara aktif dalam proses kerja.

\section{Simpulan}

Kepemimpinan berpengaruh positif dan signifikan terhadap motivasi kerja, Kepuasan berpengaruh positif dan signifikan terhadap motivasi kerja, Kepemimpinan berpengaruh positif dan signifikan terhadap kinerja pegawai, Kepuasan berpengaruh positif dan signifikan terhadap kinerja pegawai, Motivasi kerja berpengaruh positif dan signifikan terhadap kinerja pegawai, Kepemimpinan dan kepuasan berpengaruh positif dan signifikan terhadap kinerja pegawai dengan motivasi kerja sebagai variabel intervening. Penelitian ini dimasa mendatang diharapkan dapat menyajikan hasil penelitian yang berkualitas lagi dengan adanya beberapa masukan mengenai beberapa hal diantaranya untuk penelitian mendatang, dapat memperluas wilayah sampel penelitian dengan memasukan semua anggota populasi yang ada, untuk penelitian mendatang, sebaiknya menambah variabel guna mempengaruhi dan memperkuat atau memperlemah variabel dependen, seperti lingkungan organisasi, ilmu dan tegnologi dan lain-lain, penelitian mendatang, disarankan survei dengan metode lain, misalnya wawancara secara langsung agar data yang dikumpul lebih valid.

\section{REFERENSI}

Afifah, T., \& Musadieq, M. Al. (2017). Pengaruh Kepuasan Kerja Terhadap Motivasi Kerja Dan Dampaknya Terhadap Kinerja (Studi pada Karyawan PT Pertamina Geothermal Energy Kantor Pusat Jakarta). Jurnal Administrasi Bisnis (JAB), 47(1), 122129.

Alghazo, A. M., \& Al-Anazi, M. (2016). The Impact of Leadership Style on Employee's Motivation. International Journal of Economics and Business Administration, 2(5), 37-44.

Ali, A., Bin, L. Z., Piang, H. J., \& Ali, Z. (2016). The Impact of Motivation on the Employee Performance and Job Satisfaction in IT Park (Software House) Sector of Peshawar, Pakistan. International Journal of Academic Research in Business and Social Sciences, 6(9), 297-310. https://doi.org/10.6007/IJARBSS/v6i9/2311

Azhari, Z., \& Syamsir. (2012). Pengaruh Kepuasan Kerja dan Lingkungan Kerja terhadap Motivasi Kerja PNS Sekretariat DPRD Sumatera Barat. Tingkap, 8(1), 93-110.

Bahrum, S. P., \& Sinaga, I. W. (2015). Pengaruh Kepemimpinan Dan Motivasi Kerja Terhadap Kinerja Pegawai (Studi Pada Pegawai Lembaga Dewan Kawasan Perdagangan Bebas Pelabuhan Bebas Batam Bintan Karimun). Jurnal Akuntansi, Ekonomi Dan Manajemen Bisnis, 3(2), 135-141. Basit, A., \& Sebastian, V. (2017). Impact of Leadership Style on Employee Performance (A Case Study On A 


\section{Published Oktober 2018 \\ JURNAL ILMIAH MANAJEMEN DAN BISNIS \\ ISSN 1693-7619 (print) | ISSN 2580-4170 (online), http://jurnal.umsu.ac.id/index.php/mbisnis}

Private Organization In Malaysia). International Journal of Accounting \& Business Management, 5(2), 112-130.

Cong, N. N., \& Van, D. N. (2013). Effects of Motivation and Job satisfaction on Employees' Performance at Petrovietnam Nghe an Construction Joints Stock Corporation (PVNC). International Journal of Business and Social Science, 4(6), 212-217.

Fadlallh, A. W. A. (2015). Impact of Job Satisfaction on Employees Performance an Application on Faculty of Science and Humanity Studies University of Salman Bin Abdul-Aziz$\mathrm{Al}$ Aflaj. International Journal of Innovation and Research in Educational Sciences, 2(1), 26-32.

Iqbal, N., Anwar, S., \& Haider, N. (2015). Effect of Leadership Style on Employee Performance. Arabian Journal of Business and Management Review, 5(5), 1-6. https://doi.org/10.4172/22235833.1000146

Khan, A. H., Nawaz, M. M., Aleem, M., \& Hamed, W. (2012). Impact of job satisfaction on employee performance : An empirical study of autonomous Medical Institutions of Pakistan. African Journal of Business Management, 6(7), 2697-2705. https://doi.org/10.5897/AJBM11.2222

Muizu, W. O. Z. (2014). Pengaruh Kepemimpinan Terhadap Kinerja Karyawan. Pekbis Jurnal, 6(1), 1-13.

Nasution, M. I. (2018). Peran Kepuasan Kerja dan Kepemimpinan Transformasional Terhadap Kinerja Karyawan. In The National Conferences Management and Business (NCMAB) 2018 (pp. 425439). Surakarta: Universitas Muhammadiyah Surakarta.

Nugraha, Y. A. (2016). Pengaruh Gaya Kepemimpinan Terhadap Motivasi
Kerja Karyawan Pt General Finance Cabang Serang. Urnal Ilmiah Revenue, 2(2), 80-90.

Octaviannand, R., Pandjaitan, N. K., \& Kuswanto, S. (2017). Effect of Job Satisfaction and Motivation towards Employee's Performance in XYZ Shipping Company. Journal of Education and Practice, 8(8), 72-79.

Omollo, P. A., \& Oloko. (2015). Effect of motivation on employee performance of commercial banks in Kenya: A case study of Kenya Commercial Bank in Migori County Pamela. International Journal of Human Resource Studies, 5(2), 87-103.

Onanda, B. (2015). The Effects of Motivation on Job Performance A Case Study of KCB Coast Region. International Journal of Scientific and Research Publications, 5(9), 1-13.

Pradana, M. (2015). Pengaruh Gaya Kepemimpinan Terhadap Motivasi Karyawan di Ganesha Operation, Bandung. Jurnal Studi Manajemen Dan Bisnis, 2(1), 24-39.

Rasmi, Amiruddin, \& Sumardi. (2017). Compensation And Motivation Effect To Employees' Job Satisfaction. Hasanuddin Economics and Business Review, 1(2), 162-167. https://doi.org/10.26487/hebr.v

Rawung, F. H. (2013). The Effect of Leadership on the Work Motivation of Higher Education Administration Employees (Study at Manado State University). IOSR Journal of Business and Management, 15(1), 28-33.

Rindiantika, O., \& Susilo, S. H. (2018). Pengaruh Kepuasan Kerja Terhadap Kinerja Karyawan Dengan Organizational Citizenship Behavior Sebagai Variabel Intervening (Studi Pada Karyawan Ptpn X - Unit Usaha Pabrik Gula Modjopanggoong Tulungagung). Jurnal Administrasi 


\section{JURNAL ILMIAH MANAJEMEN DAN BISNIS

Bisnis (JAB), 64(1), 28-35.

Shahzadi, I., Javed, A., Pirzada, S. S.,

Nasreen, S., \& Khanam, F. (2014).

Impact of Employee Motivation on

Employee Performance. European

Journal of Business and Management, 6(23), 159-167.

Supendy, R., Setiawan, M., Troena, E. A., \&

Surachman. (2012). Pengaruh

Kepemimpinan terhadap Motivasi dan

Kinerja Karyawan serta Implikasinya

terhadap Kepuasan Kerja (Studi pada

Bank Pembangunan Daerah (BPD)

Sulawesi Tenggara). Jurnal Aplilkasi

Manajemen, 10(2), 395-405. 